\title{
PERTANIAN
}

\section{PENGARUH KONSENTRASI DAN INTERVAL PENYEMPROTAN PUPUK CAIR DARI LIMBAH KARET TERHADAP PERTUMBUHAN DAN HASIL BAWANG MERAH (Allium ascalonicum L.)}

\author{
The Effect of Concentration and Interval of Liquid Fertilizer Spraying from Rubber Waste \\ on Growth and Yield of Shallots (Allium ascalonicum L.)
}

\author{
Danar Musi Pawarta*, Wahyu Indra Duwi Fanata, Gatot Subroto, Niken Sulistyaningsih \\ Program Studi Agroteknologi, Fakultas Pertanian, Universitas Jember \\ Jalan Kalimantan No. 37 Kampus Tegalboto, Sumbersari, Jember, 68121 \\ *E-mail: danarmusi@gmail.com
}

\begin{abstract}
Rubber is one of the important plantation crops for Indonesia. Rubber production that continues to increase is inseparable from the rubber waste produced, especially rubber wastewater. Rubber liquid waste can be managed into liquid fertilizer because there are carbon and nitrogen contents that can be used by microbes as growth substrate. Exploitation of rubber liquid waste is also expected to be able to solve existing problems in the cultivation of shallots, especially in the formation of tubers and minimize the use of chemical fertilizers. This study aims to determine the effect of liquid fertilizer concentration and interval of spraying liquid fertilizer from rubber waste on the growth and yield of shallots. The liquid fertilizer concentration used is $0 \mathrm{ml} / 1$, $5 \mathrm{ml} / 1,10 \mathrm{ml} / 1$ and $15 \mathrm{ml} / 1$. The liquid fertilizer spraying interval used is 1 week, 2 weeks and 3 weeks. Data obtained next analyzed and tested using DMRT $\alpha 5 \%$. The result showed te best treatment combination for concentration of $15 \mathrm{ml} / 1$ and a spraying interval of 1 week.
\end{abstract}

Keywords: rubber waste, concentration, spraying interval, shallots

\section{ABSTRAK}

Karet merupakan salah satu tanaman perkebunan yang penting bagi Indonesia. Produksi karet yang terus meningkat tidak lepas dari limbah karet yang dihasilkan khususnya limbah cair karet. Limbah cair karet dapat dikelola menjadi pupuk cair dikarenakan terdapat kandungan karbon dan nitrogen yang dapat digunakan oleh mikroba sebagai subtrat pertumbuhan. Pemanfaatan limbah cair karet diharapkan juga dapat menyelesaikan permasalahan yang ada dalam budidaya tanaman bawang merah khususnya dala pembentukan umbi dan meminimalisir penggunaan pupuk kimia. Penelitian ini bertujuan untuk mengetahui pengaruh konsentrasi pupuk cair dan interval penyemprotan pupuk cair dari limbah karet terhadap pertumbuhan dan hasil bawang merah. Konsentrasi pupuk cair yang digunakan antara lain $0 \mathrm{ml} / 1,5 \mathrm{ml} / 1,10 \mathrm{ml} / 1$ dan $15 \mathrm{ml} / 1$. Interval penyemprotan pupuk cair yang digunakan antara lain 1 minggu, 2 minggu dan 3 minggu. Data yang diperoleh selanjutnya dianalisis dan diuji menggunakan DMRT $\alpha 5 \%$. Hasil penelitian menunjukkan kombinasi perlakuan terbaik untuk konsentrasi dan interval penyemprotan pupuk cair adalah konsentrasi $15 \mathrm{ml} / 1$ dan interval penyemprotan 1 minggu.

Kata Kunci: limbah karet, konsentrasi, interval penyemprotan, bawang merah

How to citate: Pawarta, D. M., W. I. D. Fanata, G. Subroto dan N. Sulistyaningsih. 2019. Pengaruh Konsentrasi dan Interval Penyemprotan Pupuk Cair dari Limbah Karet terhadap Pertumbuhan dan Hasil Bawang Merah (Allium ascalonicum L.) . Berkala Ilmiah Pertanian 2(3): 115-121.

\section{PENDAHULUAN}

Tanaman karet tergolong kedalam tanaman perkebunan yang dapat tumbuh diberbagai wilayah Indonesia. Karet dapat dikatakan sebagai produk dari proses terjadinya penggumpalan tanaman karet (lateks) dimana proses penggumpalan lateks tersebut selanjutnya diolah menjadi lembaran karet (sheet) dan karet remah (crumb rubber) yang dapat dijadikan sebagai bahan baku dalam industri karet. Indonesia melakukan ekspor karet dalam berbagai bentuk seperti halnya dalam bentuk bahan baku industri maupun produk olahan jadi (Salim dkk., 2015). Sebelum menjadi bahan baku olahan industri maupun bahan jadi, lateks tersebut mengalami proses pengolahan.
Salah satu jenis pengolahan karet yang diproduksi oleh perkebunan gunung pasang milik Perusahaan Daerah Perkebunan Kabupaten Jember adalah jenis karet konvensional yang bertipe Rribbed Smoked Sheet (RSS). Pengolahan karet RSS merupakan salah satu proses pengolahan karet yang membutuhkan banyak air sehingga mengakibatkan banyak limbah cair yang dihasilkan. Jumlah limbah cair yang dihasilkan relatif banyak sehingga membutuhkan penanganan yang intensif. Penanganan limbah cair lateks yang ada pada seluruh pabrik pengolahan karet alam di Indonesia menggunakan sistem kolam aerob-anaerob. Metode penanganan ini membutuhkan biaya operasional yang tinggi dikarenakan pada metode tersebut memerlukan lahan yang luas dan pemeliharaan yang intensif (Puspita dkk., 2005). Apabila limbah 
cair karet tersebut tidak tertangani dengan baik maka akan mengakibatkan pencemaran lingkungan.

Pemanfaatan limbah cair karet pada dasarnya belum banyak dilakukan, karena dalam limbah cair karet terdapat kandungan zat amonium (NH3). Kandungan amonium akan sangat berbahaya apabila dalam wujud bebas atau belum terionisasi dikarenakan bersifat toksik (SK MENLH No. 03 tahun 1991). Dampak dari zat amonium tersebut menyebabkan polusi udara, mencemari sumber air bersih dan tanaman mengalami gangguan pertumbuhan atau penurunan bobot kering akibat kerusakan sistem perakaran. Terdapat beberapa inovasi yang dapat dilakukan dalam pembuatan pupuk organik cair dengan pemanfaatan limbah pertanian yaitu limbah cair karet. Pemanfaatan limbah cair karet yang digunakan sebagai bahan baku pembuatan pupuk cair dikarenakan dalam limbah cair karet juga terdapat kandungan karbon dan nitrogen dapat digunakan mikroba asam indol asetat (indole acecit acid) sebagai subtrat pertumbuhan (Kresnawaty dkk., 2008).

Pemanfaatan limbah cair sebagai pupuk organik cair juga diharapkan dapat membantu menyelesaikan permasalahan yang ada dalam budidaya tanaman bawang merah khususnya dalam pembentukan umbi dan meminimalisir penggunaan pupuk kimia. Pemenuhan kebutuhan unsur hara bawang merah untuk mendapatkan umbi bawang merah dapat dilakukan dengan melakukan pemupukan yang disesuaikan dengan kebutuhan hara tanaman. Pemberian dosis dan interval pengaplikasian pada proses pemupukan tanaman bawang merah harus lebih efisien dan tepat sehingga bawang merah tidak mengalami kekurangan maupun kelebihan dalam penyerapan unsur hara. Proses pemupukan yang dilakukan oleh petani bawang merah pada umumnya menggunakan pupuk kimia. Penggunaan pupuk kimia pada budidaya tanaman pada dasarnya memiliki dampak negatif jangka panjang dimana tanah menjadi masam dan keras.

Berdasarkan uraian tersebut, maka dilakukan penelitian dengan pemanfaatan limbah cair karet sebagai pupuk organik cair dengan membandingkan beberapa konsentrasi dan interval penyemprotan pupuk cair terhadap pertumbuhan dan hasil bawang merah.

\section{BAHAN DAN METODE}

Waktu dan Tempat. Penelitian dilaksanakan pada bulan Juli 2018 sampai dengan September 2018, bertempat di Green House Pecoro, Kecamatan Rambipuji, Kabupaten Jember.

Alat dan Bahan. Gelas ukur, timbangan analitik, sekop, jangka sorong, penggaris, aerator gelembung, sprayer, kamera. Bahan yang digunakan antara lain bawang merah varietas bauji, limbah cair karet, molase, air kelapa, EM4, pasir, tanah, pupuk Urea, pupuk SP-36, pupuk $\mathrm{KCl}$, polybag, fungisida furadan dan fungisida dithane M-45.

Metode Percobaan. Rancangan percobaan menggunakan Rancangan Acak Lengkap (RAL) Faktorial yang terdiri dari 2 faktor. Faktor pertama yaitu konsentrasi $(\mathrm{A} 0=0 \mathrm{ml} / 1, \mathrm{~A} 1=5 \mathrm{ml} / \mathrm{l}$, $\mathrm{A} 2=10 \mathrm{ml} / 1$ A3=15 ml/l) dan Faktor kedua yaitu interval penyemprotan $(\mathrm{B} 1=1$ minggu, $\mathrm{B} 2=2$ minggu dan $\mathrm{B} 3=3$ minggu $)$. Setiap kombinasi perlakuan diulang sebanyak 3 kali sehingga didapatkan 36 satuan percobaan. Data hasil pengamatan selanjutnya dianalisis dengan menggunakan analisis sidik ragam (ANOVA). Apabila hasil dari analisis menunjukkan pengaruh nyata maka dilanjutkan dengan Uji Duncan Multiple Range Test (DMRT) dengan taraf kesalahan sebesar 5\%.

Pembuatan Pupuk Cair. Pupuk cair dibuat dengan fermentasi anaerob. Proses pembuatan pupuk cair dilakukan dengan pencampuran bahan secara bergantian dimulai dari air kelapa (1 liter), molase (5 ml/l), EM4 (5 ml/l) dan limbah cair karet (1 liter). Pupuk cair diberi aerator gelembung dan disimpan dalam ruang selama 1 minggu.

Analisis Pupuk Cair. Analisis pupuk cair dilakukan untuk mengetahui kandungan unsur hara yang terkandung. Analisis pupuk cair dilakukan di Laboratorium Pusat Penelitian Kopi dan Kakao Indonesia, Kabupaten Jember.
Tabel 1. Hasil Analisis Pupuk Cair

\begin{tabular}{lcc}
\hline \multicolumn{1}{c}{ Parameter Uji } & Metode Analisis & Hasil \\
\hline Karbon $(\mathrm{C})$ & Spektrofotometer & $0,86 \%$ \\
Nitrogen $(\mathrm{N})$ & Destilasi & $0,50 \%$ \\
Fosfor $(\mathrm{P})$ & Spektrofotometer & $158 \mathrm{ppm}$ \\
Kalium $(\mathrm{K})$ & F-AAS & $0,30 \%$ \\
Kalsium $(\mathrm{Ca})$ & F-AAS & $0,53 \%$ \\
Magnesium $(\mathrm{Mg})$ & F-AAS & $0,03 \%$ \\
$\mathrm{pH}$ & $\mathrm{pH} \mathrm{H} 2 \mathrm{O}$ & 6,55 \\
\hline
\end{tabular}

Sumber: Puslit. Kopi dan Kakao Indonesia (2018)

Analisis Tanah. Analisis tanah dilakukan untuk mengetahui kandungan unsur hara yang terkandung. Analisis pupuk cair dilakukan di Laboratorium Pusat Penelitian Kopi dan Kakao Indonesia, Kabupaten Jember.

Tabel 2. Hasil Analisis Tanah

\begin{tabular}{lcc}
\multicolumn{1}{c}{ Parameter Uji } & Metode Analisis & Hasil \\
\hline Nitrogen (N) & N-Kjeldahl & $0,16 \%$ \\
Fosfor (P) & Spektrofotometer & $80 \mathrm{ppm}$ \\
Kalium (K) & F-AAS & $1,80 \mathrm{Cmol} / \mathrm{Kg}$ \\
C-Organik & Spektrofotometer & $0,76 \%$ \\
pH & pH meter & 7,01 \\
\hline
\end{tabular}

Sumber: Puslit. Kopi dan Kakao Indonesia (2018)

Pembuatan Media Tanam. Media tanam yang digunakan yaitu campuran tanah kering angin $(4 \mathrm{~kg})$ dan pasir $(1 \mathrm{~kg})$. Memasukkan media tanam kedalam polybag kemudian diaplikasikan furadan (2 $\mathrm{g} /$ polybag). Media tanam didiamkan selama 1 minggu.

Penanaman. Penanaman dilakukan dengan kedalam lubang tanam $3 \mathrm{~cm}$. Umbi bawang merah dipilih seragam. Umbi bawang merah dipotong $1 / 4$ dibagian atas dimana dalam setiap polybag terdapat 1 umbi bawang merah.

Pemupukan. Melakukan pemupukan dasar 1 minggu sebelum taman yaitu urea sebanyak 0,69 g/polybag, SP-36 sebanyak 1,43 $\mathrm{g} /$ polybag dan $\mathrm{KCl}$ sebanyak $0,82 \mathrm{~g} /$ polybag. Pemupukan dilakukan secara bertahap sesuai perlakuan. Pemberian pupuk cair dengan konsentrasi $0 \mathrm{ml} / 1, \quad 5 \mathrm{ml} / 1,10 \mathrm{ml} / 1$ dan $15 \mathrm{ml} / 1$ dilakukan dengan interval penyemprotan 1, 2 dan 3 minggu sekali dimulai dari umur bawang merah 15 hst. Pupuk cair diaplikasiakan sebanyak 300 $\mathrm{ml} /$ polybag.

Variabel pengamatan. terdiri dari: tinggi tanaman, jumlah daun, jumlah umbi, berat segar umbi, berat kering simpan umbi, penyusutan umbi, diameter umbi, waktu panen.

\section{HASIL DAN PEMBAHASAN}

\section{Tinggi Tanaman}

Tinggi tanaman merupakan salah satu faktor penting dalam pengamatan variabel pertumbuhan dikarenakan sebagai indikator pertumbuhan tanaman. Perlakuan kombinasi konsentrasi pupuk cair dengan perlakuan interval penyemprotan pupuk cair memberikan pengaruh berbeda sangat nyata terhadap tinggi tanaman yang dihasilkan. Hasil tersebut dapat dilihat pada (Tabel 3).

Tabel 3. Interaksi Konsentrasi Pupuk Cair dan Interval Penyemprotan Pupuk Cair terhadap Tinggi Tanaman

\begin{tabular}{ccccc}
\hline \multirow{2}{*}{ Interval } & \multicolumn{4}{c}{ Konsentrasi Pupuk Cair } \\
\cline { 2 - 5 } & $\mathrm{A} 0$ & $\mathrm{~A} 1$ & $\mathrm{~A} 3$ & $\mathrm{~A} 4$ \\
\hline \multirow{2}{*}{$\mathrm{B} 1$} & $30,40 \mathrm{c}$ & $34,58 \mathrm{~b}$ & $39,78 \mathrm{a}$ & $40,77 \mathrm{a}$ \\
& $\mathrm{A}$ & $\mathrm{A}$ & $\mathrm{A}$ & $\mathrm{A}$ \\
\hline \multirow{2}{*}{$\mathrm{B} 2$} & $29,06 \mathrm{~b}$ & $31,67 \mathrm{a}$ & $32,36 \mathrm{a}$ & $32,53 \mathrm{a}$ \\
& $\mathrm{A}$ & $\mathrm{B}$ & $\mathrm{B}$ & $\mathrm{B}$ \\
\hline \multirow{2}{*}{$\mathrm{B} 3$} & $29,10 \mathrm{~b}$ & $29,83 \mathrm{ab}$ & $30,58 \mathrm{ab}$ & $31,32 \mathrm{a}$ \\
& $\mathrm{A}$ & $\mathrm{C}$ & $\mathrm{C}$ & $\mathrm{B}$ \\
\hline
\end{tabular}

Keterangan : Angka yang diikuti huruf yang berbeda pada kolom yang sama menunjukkan perbedaan yang nyata, sedangkan angka yang diikuti huruf yang berbeda pada baris yang sama menunjukkan perbedaan yang nyata menurut uji DMRT $\alpha$ 5\%. 
Berdasarkan hasil uji jarak berganda Duncan (DMRT $\alpha$ 5\%) (Tabel 3) menunjukkan interaksi pada perlakuan pemberian konsentrasi pupuk cair dan interval penyemprotan pupuk cair terhadap variabel tinggi tanaman. Terdapat perlakuan yang berbeda nyata pada pemberian konsentrasi pupuk cair A3 dan interval penyemprotan pupuk cair B1. Kombinasi perlakuan tersebut menghasilkan rata-rata nilai tinggi tanaman tertinggi sebesar 40,77 $\mathrm{cm}$. Tetapi menunjukkan hasil yang berbeda tidak nyata pada perlakuan pemberian konsentrasi pupuk cair A1 dan interval penyemprotan pupuk cair B3. Kombinasi perlakuan tersebut menghasilkan rata-rata nilai tinggi tajuk terendah sebesar $29,83 \mathrm{~cm}$. Kedua kombinasi perlakuan A3B1 dan A1B3 terdapat selisih nilai rata-rata tinggi tanaman bawang merah sebesar $10,94 \mathrm{~cm}$.

\section{Jumlah Daun}

Jumlah daun dapat dikatakan sebagai salah satu faktor penting dalam pengamatan variabel pertumbuhan dikarenakan berperan sebagai indikator pertumbuhan tanaman. Perlakuan kombinasi konsentrasi pupuk cair dengan perlakuan interval penyemprotan pupuk cair memberikan pengaruh berbeda sangat nyata terhadap jumlah daun yang dihasilkan. Hasil tersebut dapat dilihat pada (Tabel 4).

Tabel 4. Interaksi Konsentrasi Pupuk Cair dan Interval Penyemprotan Pupuk Cair terhadap Jumlah Daun.

\begin{tabular}{ccccc}
\hline \multirow{2}{*}{ Interval } & \multicolumn{4}{c}{ Konsentrasi Pupuk Cair } \\
\cline { 2 - 5 } & $\mathrm{A} 0$ & $\mathrm{~A} 1$ & $\mathrm{~A} 3$ & $\mathrm{~A} 4$ \\
\hline \multirow{2}{*}{$\mathrm{B} 1$} & $25,17 \mathrm{c}$ & $30,58 \mathrm{c}$ & $39,00 \mathrm{a}$ & $39,50 \mathrm{a}$ \\
& $\mathrm{A}$ & $\mathrm{A}$ & $\mathrm{A}$ & $\mathrm{A}$ \\
\hline \multirow{2}{*}{$\mathrm{B} 2$} & $25,00 \mathrm{~d}$ & $28,42 \mathrm{c}$ & $30,85 \mathrm{~b}$ & $32,25 \mathrm{a}$ \\
& $\mathrm{A}$ & $\mathrm{B}$ & $\mathrm{B}$ & $\mathrm{B}$ \\
\hline \multirow{2}{*}{$\mathrm{B} 3$} & $24,67 \mathrm{c}$ & $25,83 \mathrm{~b}$ & $25,83 \mathrm{~b}$ & $28,42 \mathrm{a}$ \\
& $\mathrm{A}$ & $\mathrm{C}$ & $\mathrm{C}$ & $\mathrm{C}$ \\
\hline
\end{tabular}

Keterangan : Angka yang diikuti huruf yang berbeda pada kolom yang sama menunjukkan perbedaan yang nyata, sedangkan angka yang diikuti huruf yang berbeda pada baris yang sama menunjukkan perbedaan yang nyata menurut uji DMRT $\alpha 5 \%$.

Berdasarkan hasil uji jarak berganda Duncan (DMRT $\alpha$ 5\%) (Tabel 4) menunjukkan interaksi pada perlakuan pemberian konsentrasi pupuk cair dan interval penyemprotan pupuk cair terhadap variabel jumlah daun. Terdapat perlakuan yang berbeda nyata pada pemberian konsentrasi pupuk cair A3 dan interval penyemprotan pupuk cair B1. Kombinasi perlakuan tersebut menghasilkan rata-rata nilai jumlah daun tertinggi sebesar 39,50 helai. Tetapi menunjukkan hasil berbeda tidak nyata pada perlakuan pemberian konsentrasi pupuk cair A1 dan interval penyemprotan pupuk cair B3. Kombinasi perlakuan tersebut menghasilkan ratarata nilai jumlah daun terendah sebesar 25,83 helai. Selain itu kombinasi perlakuan konsentrasi A2 dan interval penyemprotan pupuk cair B3. Kombinasi perlakuan tersebut menghasilkan ratarata nilai jumlah daun terendah sebesar 25,83 helai. Kedua kombinasi perlakuan A3B1, A1B3 dan A2B3 terdapat selisih nilai rata-rata jumlah daun bawang merah sebesar 13,67 helai.

\section{Jumlah Umbi}

Perlakuan konsentrasi pupuk cair dan perlakuan interval penyemprotan pupuk cair memberikan pengaruh berbeda sangat nyata terhadap jumlah umbi yang dihasilkan, akan tetapi interaksi kedua perlakuan memberikan pengaruh berbeda tidak nyata terhadap jumlah umbi yang dihasilkan.

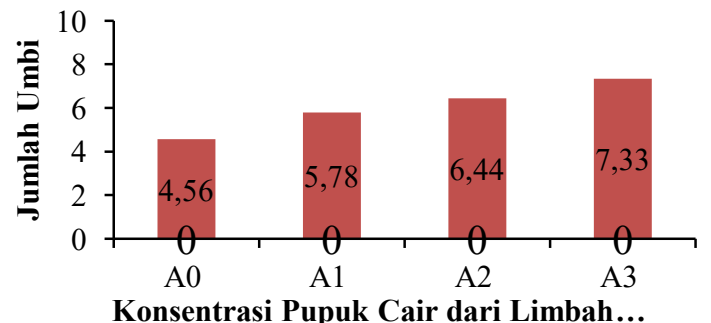

Gambar 1. Pengaruh Konsentrasi Pupuk Cair terhadap Jumlah Umbi
Berdasarkan hasil uji jarak berganda Duncan (DMRT $\alpha$ 5\%) (Gambar 1) menunjukkan bahwa terdapat perbedaan yang nyata pada perlakuan konsentrasi pupuk cair. Perlakuan konsentrasi pupuk cair A3 menunjukkan rata-rata nilai jumlah umbi tertinggi sebesar 7,33. Tetapi berbeda tidak nyata pada perlakuan konsentrasi pupuk cair A1 menunjukkan rata-rata nilai jumlah umbi terendah sebesar 5,78. Dari perbedaan tersebut antara perlakuan A3 dengan A1 menunjukkan selisih rata-rata nilai jumlah umbi sebesar 1,55. Perlakuan konsentrasi pupuk cair A3 menunjukkan hasil yang lebih baik dibandingkan dengan perlakuan konsentrasi pupuk cair lainnya.

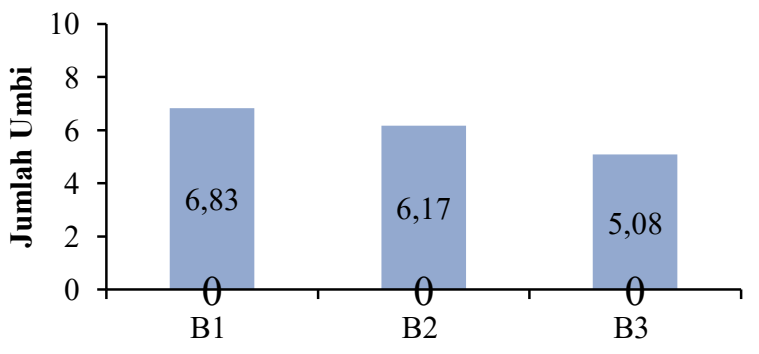

Interval Penyemprotan Pupuk Cair

Gambar 2. Pengaruh Interval Penyemprotan Pupuk Cair terhadap Jumlah Umbi

Berdasarkan hasil uji jarak berganda Duncan (DMRT $\alpha$ 5\%) (Gambar 2) menunjukkan bahwa terdapat perbedaan yang nyata pada perlakuan interval penyemprotan pupuk cair. Perlakuan interval penyemprotan pupuk B1 menunjukkan rata-rata nilai jumlah umbi tertinggi sebesar 6,83 . Tetapi berbeda tidak nyata pada perlakuan interval penyemprotan pupuk cair B3 menunjukkan ratarata nilai jumlah umbi terendah sebesar 5,08. Perbedaan hasil tersebut antara perlakuan B1 dengan B3 menunjukkan selisih ratarata nilai jumlah umbi sebesar 1,75. Perlakuan interval penyemprotan pupuk cair 1 minggu menunjukkan hasil yang lebih baik dibandingkan dengan perlakuan interval penyemprotan pupuk cair 2 minggu dan 3 minggu.

\section{Berat Segar Umbi}

Perlakuan konsentrasi pupuk cair dan perlakuan interval penyemprotan pupuk cair memberikan pengaruh berbeda sangat nyata terhadap berat segar umbi yang dihasilkan, akan tetapi interaksi kedua perlakuan memberikan pengaruh berbeda tidak nyata terhadap berat segar umbi yang dihasilkan.

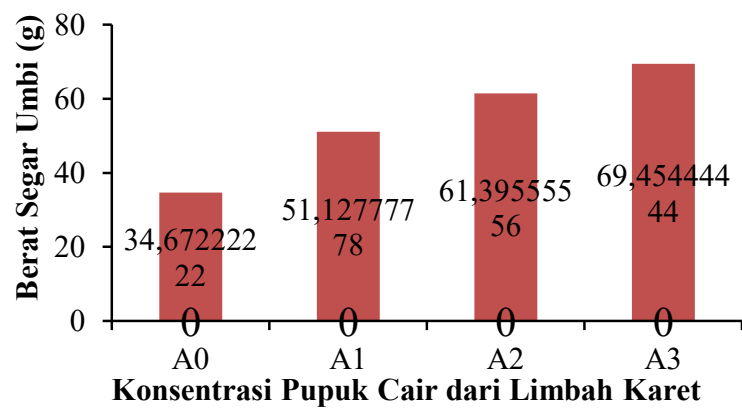

Gambar 3. Pengaruh Konsentrasi Pupuk Cair terhadap Berat Segar Umbi

Berdasarkan hasil uji jarak berganda Duncan (DMRT $\alpha$ 5\%) (Gambar 3) menunjukkan bahwa terdapat perbedaan yang nyata pada perlakuan konsentrasi pupuk cair. Perlakuan konsentrasi pupuk cair A3 menunjukkan rata-rata nilai berat segar umbi tertinggi sebesar 69,65 g. Tetapi berbeda tidak nyata pada perlakuan konsentrasi pupuk cair A1 menunjukkan rata-rata nilai berat segar umbi terendah sebesar 51,13 g. Dari perbedaan tersebut antara perlakuan A3 dengan A1 menunjukkan selisih rata-rata nilai berat segar umbi sebesar 18,52 g. Perlakuan konsentrasi pupuk cair A3 menunjukkan hasil yang lebih baik dibandingkan dengan perlakuan konsentrasi pupuk cair lainya. 


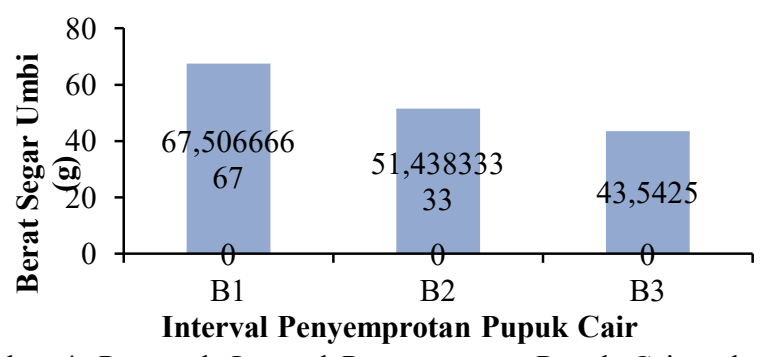

Gambar 4. Pengaruh Interval Penyemprotan Pupuk Cair terhadap Berat Segar Umbi

Berdasarkan hasil uji jarak berganda Duncan (DMRT a 5\%) (Gambar 4) menunjukkan bahwa terdapat perbedaan yang nyata pada perlakuan interval penyemprotan pupuk cair. Perlakuan interval penyemprotan pupuk cair B1 menunjukkan hasil rata-rata nilai berat segar umbi tertinggi sebesar $66,51 \mathrm{~g}$. Berbeda tidak nyata pada perlakuan interval penyemprotan pupuk cair B3 menunjukkan rata-rata nilai berat segar umbi terendah sebesar 43,54 g. Dari perbedaan tersebut antara perlakuan B1 dengan B3 menunjukkan selisih rata-rata nilai berat segar umbi sebesar 22,97 g. Perlakuan interval penyemprotan pupuk cair B1 menunjukkan hasil yang lebih baik dibandingkan dengan perlakuan interval penyemprotan pupuk cair B2 dan B3.

\section{Berat Kering Simpan Umbi}

Perlakuan konsentrasi pupuk cair dan perlakuan interval penyemprotan pupuk cair memberikan pengaruh sangat berbeda nyata terhadap berat kering simpan umbi yang dihasilkan, akan tetapi interaksi kedua perlakuan memberikan pengaruh yang berbeda tidak nyata terhadap berat kering simpan umbi yang dihasilkan.

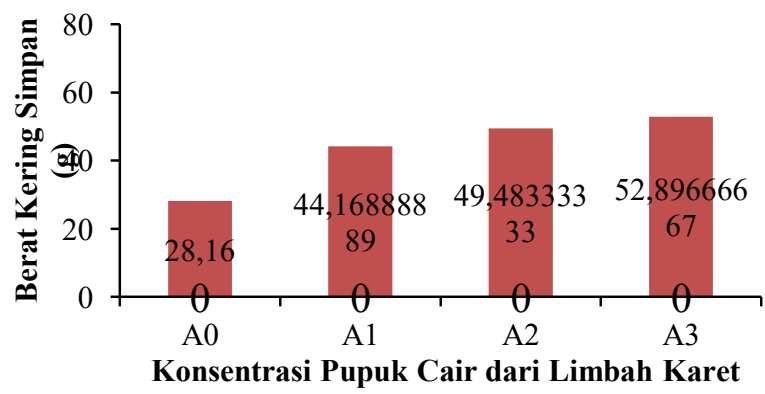

Gambar 5. Pengaruh Konsentrasi Pupuk Cair terhadap Berat Kering Simpan Umbi

Berdasarkan hasil uji jarak berganda Duncan (DMRT $\alpha$ 5\%) (Gambar 5) menunjukkan bahwa terdapat perbedaan yang nyata pada perlakuan konsentrasi pupuk cair. Perlakuan konsentrasi pupuk cair A3 menunjukkan rata-rata nilai berat kering simpan umbi tertinggi sebesar 52,90 g. Tetapi berbeda tidak nyata pada perlakuan konsentrasi pupuk cair A1 menunjukkan rata-rata nilai berat kering simpan umbi terendah sebesar 44,17 g. Dari perbedaan tersebut antara perlakuan A3 dengan A1 menunjukkan selisih rata-rata nilai berat kering simpan umbi sebesar 8,73 g. Perlakuan konsentrasi pupuk cair A3 menunjukkan hasil yang lebih baik dibandingkan dengan perlakuan konsentrasi pupuk cair lainya.

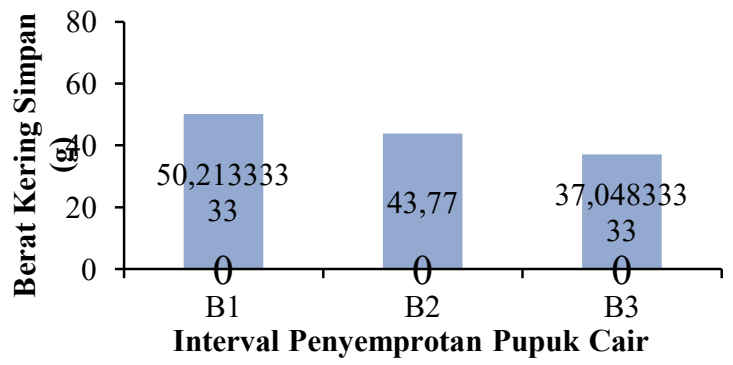

Gambar 6. Pengaruh Interval Penyemprotan Pupuk Cair terhadap Berat Kering Simpan Umbi
Berdasarkan hasil uji jarak berganda Duncan (DMRT $\alpha$ 5\%) (Gambar 6) menunjukkan bahwa terdapat perbedaan yang nyata pada perlakuan interval penyemprotan pupuk cair. Perlakuan interval penyemprotan pupuk B1 menunjukkan rata-rata nilai berat segar umbi tertinggi sebesar 50,21 g. Berbeda tidak nyata pada perlakuan interval penyemprotan pupuk cair B3 menunjukkan ratarata nilai berat segar umbi terendah sebesar 37,05 g. Dari perbedaan tersebut antara perlakuan B1 dengan B3 menunjukkan selisih ratarata nilai berat kering simpan umbi sebesar 27,24 g. Perlakuan interval penyemprotan pupuk cair B1 menunjukkan hasil yang lebih baik dibandingkan dengan perlakuan interval penyemprotan pupuk cair B2 dan B3.

\section{Penyusutan Umbi}

Penyusutan umbi merupakan salah satu variabel pengamatan yang digunakan untuk menunjukkan kondisi umbi bawang merah. Perlakuan kombinasi konsentrasi dengan perlakuan interval penyemprotan pupuk cair memberikan pengaruh berbeda nyata terhadap penyusutan umbi yang dihasilkan. Hasil tersebut dapat dilihat pada (Tabel 5).

Tabel 5. Interaksi Konsentrasi Pupuk Cair dan Interval Penyemprotan Pupuk Cair terhadap Penyusutan Umbi.

\begin{tabular}{ccccc}
\hline \multirow{2}{*}{ Interval } & \multicolumn{4}{c}{ Konsentrasi Pupuk Cair } \\
\cline { 2 - 5 } & $\mathrm{A} 0$ & $\mathrm{~A} 1$ & $\mathrm{~A} 3$ & $\mathrm{~A} 4$ \\
\hline $\mathrm{B} 1$ & $16,97 \mathrm{~b}$ & $14,05 \mathrm{~b}$ & $26,29 \mathrm{a}$ & $3,10 \mathrm{c}$ \\
& $\mathrm{A}$ & $\mathrm{A}$ & $\mathrm{A}$ & $\mathrm{B}$ \\
& $23,31 \mathrm{a}$ & $14,19 \mathrm{~b}$ & $13,73 \mathrm{~b}$ & $11,67 \mathrm{~b}$ \\
$\mathrm{~B} 2$ & $\mathrm{~A}$ & $\mathrm{~A}$ & $\mathrm{~B}$ & $\mathrm{~A}$ \\
& $17,77 \mathrm{a}$ & $16,80 \mathrm{a}$ & $14,05 \mathrm{a}$ & $13,82 \mathrm{a}$ \\
$\mathrm{B} 3$ & $\mathrm{~A}$ & $\mathrm{~A}$ & $\mathrm{~B}$ & $\mathrm{~A}$ \\
\hline
\end{tabular}

Keterangan : Angka yang diikuti huruf yang berbeda pada kolom yang sama menunjukkan perbedaan yang nyata, sedangkan angka yang diikuti huruf yang berbeda pada baris yang sama menunjukkan perbedaan yang nyata menurut uji DMRT $\alpha 5 \%$.

Berdasarkan hasil uji jarak berganda Duncan (DMRT $\alpha$ 5\%) (Tabel 5) menunjukkan interaksi pada perlakuan pemberian konsentrasi pupuk cair dan interval penyemprotan pupuk cair terhadap variabel penyusutan umbi. Terdapat perlakuan yang berbeda nyata pada pemberian konsentrasi pupuk cair A3 dan interval penyemprotan pupuk cair B1. Kombinasi perlakuan tersebut menghasilkan rata-rata nilai penyusutan terendah sebesar 3,10. Tetapi menunjukkan hasil berbeda tidak nyata pada perlakuan pemberian konsntrasi pupuk cair A1 dan interval penyemprotan pupuk cair B3. Kombinasi perlakuan tersebut menghasilkan ratarata nilai penyusutan tertinggi sebesar 16,80 . Kedua kombinasi perlakuan A3B1 dan A1B3 terdapat selisih nilai rata-rata jumlah daun bawang merah sebesar 13,70.

\section{Diameter Umbi}

Perlakuan konsentrasi pupuk cair dan perlakuan interval penyemprotan pupuk cair memberikan pengaruh sangat berbeda nyata terhadap diameter umbi yang dihasilkan, akan tetapi interaksi kedua perlakuan memberikan pengaruh yang berbeda tidak nyata terhadap diameter umbi yang dihasilkan.

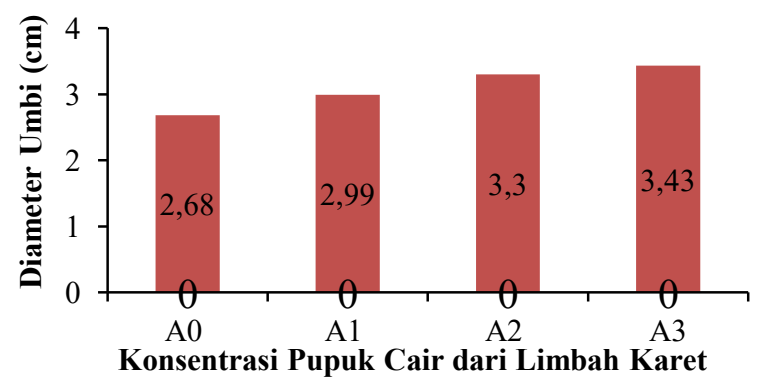

Gambar 7. Pengaruh Konsentrasi Pupuk Cair terhadap Diameter Umbi 
Berdasarkan hasil uji jarak berganda Duncan (DMRT $\alpha$ 5\%) (Gambar 7) menunjukkan bahwa terdapat perbedaan yang nyata pada perlakuan konsentrasi pupuk cair. Perlakuan konsentrasi pupuk cair A3 menunjukkan rata-rata nilai diameter umbi tertinggi sebesar $3,43 \mathrm{~cm}$. Tetapi berbeda tidak nyata pada perlakuan konsentrasi pupuk cair A1 menunjukkan rata-rata nilai diameter umbi terendah sebesar 2,99 $\mathrm{cm}$. Dari perbedaan tersebut antara perlakuan A3 dengan A1 menunjukkan selisih rata-rata nilai jumlah umbi sebesar $0,44 \mathrm{~cm}$. Perlakuan konsentrasi pupuk cair A3 menunjukkan hasil yang lebih baik dibandingkan dengan perlakuan konsentrasi pupuk cair lainya.

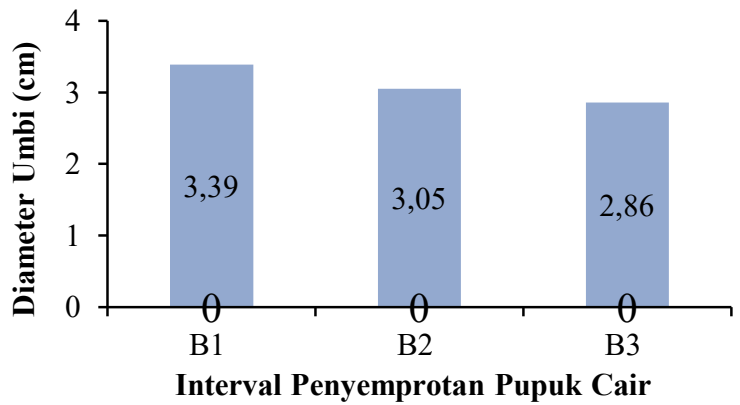

Gambar 8. Pengaruh Interval Penyemprotan Pupuk Cair terhadap Diameter Umbi

Berdasarkan hasil uji jarak berganda Duncan (DMRT $\alpha$ 5\%) (Gambar 8) menunjukkan bahwa terdapat perbedaan yang nyata pada perlakuan interval penyemprotan pupuk cair. Perlakuan interval penyemprotan pupuk cair B1 menunjukkan rata-rata nilai diameter umbi tertinggi sebesar $3,39 \mathrm{~cm}$. Tetapi berbeda tidak nyata pada perlakuan interval penyemprotan pupuk cair B3 menunjukkan rata-rata nilai diameter umbi terendah sebesar $2,86 \mathrm{~cm}$. Dari perbedaan tersebut antara perlakuan B1 dengan B3 menunjukkan selisih rata-rata nilai berat segar umbi sebesar $0,53 \mathrm{~cm}$. Perlakuan interval penyemprotan pupuk cair B1 menunjukkan hasil yang lebih baik dibandingkan dengan perlakuan interval penyemprotan pupuk cair B2 dan B3.

\section{Waktu Panen}

Waktu panen merupakan satu variabel pengamatan yang digunakan untuk menunjukkan kondisi tanaman bawang merah dimana umbi bawang merah dapat dipanen. Perlakuan kombinasi konsentrasi pupuk cair dengan perlakuan interval penyemprotan pupuk cair memberikan pengaruh berbeda sangat nyata terhadap waktu panen yang dihasilkan. Hasil tersebut dapat dilihat pada (Tabel 6).

Tabel 6. Interaksi Konsentrasi Pupuk Cair dan Interval Penyemprotan Pupuk Cair terhadap Waktu Panen

\begin{tabular}{ccccc}
\hline \multirow{2}{*}{ Interval } & \multicolumn{4}{c}{ Konsentrasi Pupuk Cair } \\
\cline { 2 - 5 } & $\mathrm{A} 0$ & $\mathrm{~A} 1$ & $\mathrm{~A} 3$ & $\mathrm{~A} 4$ \\
\hline \multirow{2}{*}{$\mathrm{B} 1$} & $63,00 \mathrm{a}$ & $60,33 \mathrm{~b}$ & $59,33 \mathrm{c}$ & $58,00 \mathrm{~d}$ \\
& $\mathrm{~A}$ & $\mathrm{~B}$ & $\mathrm{C}$ & $\mathrm{B}$ \\
$\mathrm{B} 2$ & $63,00 \mathrm{a}$ & $61,33 \mathrm{~b}$ & $60,67 \mathrm{c}$ & $60,33 \mathrm{~d}$ \\
& $\mathrm{~A}$ & $\mathrm{~A}$ & $\mathrm{~B}$ & $\mathrm{~A}$ \\
& $63,00 \mathrm{a}$ & $61,67 \mathrm{~b}$ & $61,33 \mathrm{~b}$ & $60,67 \mathrm{c}$ \\
B3 & $\mathrm{A}$ & $\mathrm{A}$ & $\mathrm{A}$ & $\mathrm{A}$ \\
\hline
\end{tabular}

Keterangan : Angka yang diikuti huruf yang berbeda pada kolom yang sama menunjukkan perbedaan yang nyata, sedangkan angka yang diikuti huruf yang berbeda pada baris yang sama menunjukkan perbedaan yang nyata menurut uji DMRT $\alpha 5 \%$.

Berdasarkan hasil uji jarak berganda Duncan (DMRT a 5\%) (Tabel 10) menunjukkan interaksi pada perlakuan pemberian konsentrasi pupuk cair dan interval penyemprotan pupuk cair terhadap variabel waktu panen. Terdapat perlakuan yang berbeda nyata pada pemberian konsentrasi pupuk cair A3 dan interval penyemprotan pupuk cair B1. Kombinasi perlakuan tersebut menghasilkan rata-rata nilai waktu panen tertinggi sebesar 58,00 hari. Tetapi menunjukkan hasil yang berbeda tidak nyata pada perlakuan konsentrasi pupuk cair A1 dan interval penyemprotan pupuk cair B3. Kombinasi perlakuan tersebut menghasilkan ratarata nilai waktu panen terendah sebesar 61,67 hari. Kedua kombinasi perlakuan $\mathrm{A} 3 \mathrm{~B} 1, \mathrm{~A} 1 \mathrm{~B} 3$ dan $\mathrm{A} 2 \mathrm{~B} 3$ terdapat selisih ratarata nilai waktu panen bawang merah sebesar 3,67 hari.

Pertumbuhan dan hasil tanaman bawang merah dipengaruhi oleh beberapa faktor seperti genetik tanaman, iklim, organisme pengganggu tanaman, dan kesuburan tanaman (Prihandana dan Hendroko, 2007). Kesuburan tanaman dapat dipenuhi dengan dilakukannya pemupukan yang berimbang sehingga dapat meningkatkan pertumbuhan dan hasil tanaman bawang merah. Pemberian konsentrasi pupuk dan interval penyemprotan pupuk cair sesuai perlakuan menunjukkan hasil yang sangat berbeda nyata. Pertumbuhan dan perkembangan bawang merah berjalan normal dikarenakan konsentrasi pupuk yang diaplikasikan berada pada kondisi cukup dan tidak berlebihan.

Interval penyemprotan pupuk dapat menentukan pertumbuhan tanaman. Perbedaan waktu penyemprotan pupuk akan memberikan hasil yang berbeda pada pertumbuhan tanaman. Pemberian pupuk yang terlalu sering akan mengakibatkan pemborosan pupuk sedangkan pemberian pupuk yang jarang akan menyebabkan kebutuhan hara tanaman kurang terpenuhi (Azyyati, 2016). Berdasarkan hasil penelitian dimana dari ketiga interval penyemprotan pupuk cair yaitu 1 minggu sekali, 2 minggu sekali, dan 3 minggu sekali mendapatkan hasil yang berbeda. Interval penyemprotan pupuk cair 1 minggu sekali memberikan hasil yang baik bagi pertumbuhan dan hasil tanaman bawang merah pada setiap parameter pengamatan dibandingkan dengan taraf interval lainnya. Hal tersebut dikarenakan kebutuhan unsur hara tanaman bawang merah terpenuhi dengan pemberian pupuk secara intensif.

Adanya pertambahan tinggi tanaman maka tanaman tersebut mengalami pembelahan dan pembesaran sel khususnya di jaringan meristem. Meristem ujung akan mengasilkan sel baru baik yang ada di ujung akar maupun ujung batang, sehingga memberikan respon tanaman bertambah tinggi. Perkembangan dan pertambahan tinggi dipengaruhi oleh adanya penyerapan unsur hara yang langsung diangkut dan diolah dalam proses fotosintesis. Pernyataan tersebut didukung oleh Marscher (1986) dalam Fahmi dkk., (2010) daun tanaman akan tumbuh besar dan permukaan daun semakin luas apabila kebutuhan $\mathrm{N}$ tanaman telah terpenuhi. Kebutuhan nitrogen tercukupi kerja auksin akan terpacu sehingga akan mempengaruhi pertumbuhan tanaman. Unsur nitrogen digunakan sebagai penyusun utama klorofil dan protein tanaman. Menurut Hardjowigeno (2010) menyatakan bahwa, unsur hara fosfor berperan dalam pembelahan sel, pembentukan buah hingga mempercepat pemasakan buah.

Unsur $\mathrm{N}$ berperan dalam pertumbuhan vegetatif sedangkan unsur $\mathrm{P}$ berperan dalam proses pembentukan tunas. Semakin banyak unsur hara $\mathrm{N}$ dan $\mathrm{P}$ yang tersedia bagi tanaman maka proses pembentukan sel dibagian tunas akan semakin meningkat sehingga mendorong terbentuknya daun baru. Unsur P dibutuhkan tanaman dalam proses pembentukan sel dan jaringan akar yang sedang mengalami proses pertumbuhan (Liferdi, 2010). Menurut Sutapradja dan Sumarni (1996) menyatakan bahwa, unsur nitrogen sangat penting bagi tanaman dikarenakan dapat merangsang pertumbuhan vegetatif, penyusunan pembentukan klorofil hingga pembentukan protein dalam proses fotosintesis. Menurut Wulandari dkk (2016), nitrogen mempengaruhi proses pembesaran sel dan pembelahan sel. Pertambahan ukuran sel akan menghasilkan pertambahan ukuran jaringan dan organ yang pada akhirnya dapat meningkatkan ukuran organ tanaman secara keseluruhan.

Banyaknya jumlah umbi bawang merah yang dihasilkan dipengaruhi oleh banyaknya jumlah daun. Semakin banyak jumlah anakan maka semakin banyak jumlah umbi yang dihasilkan. Menurut Sogbedji et al., (2015) menyatakan bahwa, jumlah daun mempengaruhi jumlah umbi dimana terjadinya korelasi dengan akivitas fotosintesis yang tinggi sehingga menghasilkan fotosintat yang disimpan sebagai umbi bawang merah. Selain itu, ketersediaan nutrisi yang dibutuhkan oleh tanaman bawang harus terpenuhi. Menurut Tandi dkk., (2015) menyatakan bahwa, ketersediaan nutrisi pada tanaman dapat mempengaruhi proses pertumbuhan tanaman seperti halnya jumlah anakan daun bawang merah. 
Berat segar tanaman merupakan hasil pertumbuhan tanaman yang memanfaatkan energi cahaya matahari untuk proses fotosintesis secara maksimal. Berat segar umbi bawang merah yang dihasilkan dipengaruhi oleh tinggi tanaman dan jumlah daun. Semakin meningkat tinggi tanaman dan jumlah daun maka semakin banyak kloroplas yang ada didalam daun. Peningkatan jumlah kloroplas tersebut akan mempengaruhi proses fotosintesis dimana fotosintat akan terus meningkat. Fotosintat tersebut ditranslokasikan keseluruh bagian tanaman termasuk kadalam umbi. Seiring dengan meningkatnya proses fotosintesis dan translokasi fotosintat dari daun akan menyebabkan berat umbi bawang merah akan meningkat. Hal tersebut dikarenakan terdapat unsur nitrogen yang berperan dalam proses fotosintesis. Unsur nitrogen dapat berpengaruh dalam meningkatkan perbandingan protoplasma terhadap dinding sel yang tipis. Keadaan ini mengakibatkan umbi banyak mengandung air, sehingga tanaman yang dipupuk dengan nitrogen memiliki kadar air yang tinggi didalam sel (Salisbury dan Rose, 1995).

Berat kering dapat dikatakan sebagai akumulasi fotosintat pada sel dan jaringan tanaman. Peningkatan berat kering simpan umbi sejalan dengan peningkatan tinggi tajuk, jumlah daun, jumlah umbi hingga berat segar umbi bawang merah. Djunaedy (2009) menyatakan bahwa, aktivitas fotosintesis yang semakin meningkat disebabkan oleh banyaknya kloroplas pada daun. Proses fotosintesis yang berjalan efektif akan menghasilkan fotosintat dalam jumlah banyak dan berpengaruh dalam meningkatkan kandungan bahan kering tanaman seperti berat kering umbi.

Penyusutan bobot umbi dipengaruhi oleh kadar air dan suhu penyimpanan. Kadar air memiliki peranan penting dalam penyimpanan umbi. Kadar air yang terlalu tinggi pada awal penyimpanan dapat menyebabkan umbi bawang merah membusuk. Namun kadar air yang terlalu rendah akan menyebabkan umbi bawang merah menyusut.

Besar kecilnya diameter umbi bawang merah dapat dipengaruhi oleh beberapa faktor. Faktor tersebut salah satunya yaitu adanya proses fotosintesis yang terjadi didalam daun. Proses fotosintesis tersebut menghasilkan fotosintat yang disimpan dalam umbi sehingga umbi bawang merah akan bertambah besar. Umbi bawang merah yang bertambah besar tersebut terjadi ketika proses fotosintesis terjadi secara terus menerus dikarenakan bertambahnya jumlah daun dan disertai meningkatnya tinggi tajuk.

Bawang merah dipanen disesuaikan dengan karakteristik bawang siap panen. Panen dilakukan dengan ciri-ciri fisik tanaman, pangkal daun sudah lemas, umbi telah terbentuk, umbi sudah terlihat dipermukaan tanah, dan umbi telah bewarna merah tua atau merah keunguan (Irfan, 2013). Waktu panen dapat dipengaruhi oleh beberapa faktor. Salah satu faktor yang dapat mempengaruhi waktu panen yaitu unsur hara. Pemberian pupuk cair dari limbah karet yang telah dilakukan pada tanaman bawang merah tidak terlihat terjadinya hambatan pertumbuhan secara nyata dan tanaman tumbuh subur. Hal ini disebabkan karena pada limbah cair karet juga terkandung berbagi unsur esensial yang cukup tinggi seperti nitrogen, fosfor, kalium, kalsium dan sebagainya.

Berdasarkan hasil penelitian yang telah dilakukan, dapat diambil kesimpulan bahwa pupuk cair dari limbah karet memberikan pengaruh terhadap pertumbuhan dan hasil bawang merah. Interaksi antara konsentrasi pupuk cair $15 \mathrm{ml} / 1$ dengan interval penyemprotan pupuk cair 1 minggu menunjukkan pengaruh yang lebih baik terhadap semua variabel pengamatan. Pemberian konsentrasi pupuk cair $15 \mathrm{ml} / 1$ secara keseluruhan menunjukkan pengaruh yang baik terhadap semua variabel pengamatan. Interval penyemprotan pupuk cair 1 minggu secara keseluruhan menunjukkan pengaruh yang baik terhadap semua variabel pengamatan.

\section{KESIMPULAN}

Hasil penelitian menunjukkan kombinasi perlakuan terbaik untuk konsentrasi dan interval penyemprotan pupuk cair adalah konsentrasi $15 \mathrm{ml} / 1$ dan interval penyemprotan 1 minggu.

\section{DAFTAR PUSTAKA}

Azyyati, R., Rosita, dan Meiriani. 2016. Respons Pertumbuhan dan Produksi Tanaman Bawang Merah (Allium ascalonicumi L.) terhadap Dosis Pupuk Organik Cair Titonia (Tithonia diversifola (Hemsl. Gray) dan Interval Waktu Pemberian. Agroekoteknologi, 4(4): 2435-2446.

Balai Penelitian Tanah. 2005. Analisis Kimia Tanah, Tanaman, Air dan Pupuk. Bogor: Badan Penelitian dan Pengembangan Pertanian.

Djunaedy, A. 2009. Pengaruh Jenis dan Dosis Pupuk Bokashi terhadap Pertumbuhan dan Hasil Kacang Panjang (Vigna sinensis L.). Agrovigor, 2(1): 42-46.

Fahmi, A. Syamsudin, S. N. H. Utami, dan B. Radjagukguk. 2010. Pengaruh Interaksi Hara Nitrogen dan Fosfor terhadap Pertumbuhan Tanaman Jagung (Zea Mays L.) pada Tanah Regosol dan Latosol. Berita Biologi, 10(3): 297-304.

Hardjowigeno. 1990. Dasar Ilmu Tanah. Jakarta: Akadmika Pressindo.

Irfan, M. 2013. Respon Bawang Merah (Allium ascalonicum L.) terhadap Zat Pengatur Tumbuh dan Unsur Hara. Agroteknologi, 3(2) : 35-40.

Keputusan Menteri Negara Lingkungan Hidup Nomor: Kep45/MENLH/03/1991 Tentang Baku Mutu Limbah Cair Bagi Kesehatan Industri. Diakses pada tanggal 28 Maret 2019.

Kresnawaty, I., S. Andanawarih, Suharyanto, dan T. Panji. 2008. Optimisasi dan Pemurnian IAA yang Dihasilkan Rhizobium sp. dalam Medium Serum Lateks dengan Suplementasi Triptofan dari Pupuk Kandang. Menara Perkebunan, 76(2) : 74-82.

Liferdi, L. 2010. Effek Pemberian Fosfor terhadap Pertumbuhan Status Hara pada Bibit Manggis. Hort, 20(1): 1-9.

Peraturan Menteri Pertanian. 2011. Pupuk Organik, Pupuk Hayati dan Pembenah Tanah http://www.perundangan.pertanian.go.id. Diakses pada tanggal 28 Maret 2019.

Puspita, L., E. Ratnawati, I. N. N. Suryadiputra, dan A. A. Meutia. 2005. Lahan Basah Buatan di Indonsia. Bogor: Wetlands International Indonesia Programme.

Rahayu, E., dan Berlian V. A. 2004. Bawang Merah. Jakarta: Penebar Swadaya.

Rahmah, A., M. Izzati, dan S. Parman. 2014. Pengaruh Pupuk Organik Cair Berbahan Dasar Limbah Sawi Putih (Brassica chinensis L.) Terhadap Pertumbuhan Tanaman Jagung Manis (Zea mays L. var. Saccharata). Anatomi dan Fisiologi, 22(1): 65-79.

Reinnoki, R., W. Rohim, dan S. Priyanto. 2012. Ekstraksi Fosfor dari Limbah Buah Jengkol dan Petai Untuk Pembuatan Pupuk Organik Cair. Teknologi Kimia dan Industri, 1(1): 495-501

Riyanto. 2013. Limbah Bahan Berbahaya dan Beracun. Yogyakarta: Depublish.

Salim, Akhyar., Z. A. Noli, dan Suwirmen. 2015. Pertumbuhan Bibit Karet (Hevea brasiliensis Mull Arg.) setelah Pemberian Beberapa Dosis Fungi Mikoriza Arbuskula (FMA) Indigeneous dari Hutan Pendidikan dan Penelitian 
Biologi (HPPB) Universitas Andalan Padang.Biologi Universitas Andalas, 4(1): 31-37.

Salisbury, F. B., dan C. W. Ross. 1995. Fisiologi Tumbuhan. Bandung: ITB.

Sogbedji, J. M., L. K. Agboyi, K.S. Detchinli, R. Acthoglo, dan M. Mazinagou. 2015. Sustaining Improved Cassava Production on West African Ferrasols Through Appropriate Varieties and Optimal Potassium Fertilization Schemes. Plant Sciences, 3(1): 117-122.

Sutapradja, H. dan N. Sumarni. 1996. Pengaruh Dosis Pengapuran dan Kombinasi $\mathrm{N}$ dan $\mathrm{P}$ terhadap Pertumbuhan dan Hasil Tomat. Hortikultura, 6(3): 263-268.

Tandi, O. G., J. Paulus, dan A. Pinaria. 2015. Pertumbuhan dan Produksi Bawang Merah (Allium ascalonicum L.) Berbasis Aplikasi Biourine Sapi. Eugenia, 21(3): 142-150.

Wulandari, W., Idwar, dan Muniarti.2016. Pengaruh Pupuk Organik dalam Mengefisienkan Pupuk Nitrogen untuk Pertumbuhan dan Produksi Tanaman bawang Merah (Allium ascalonicum L.). JOM Faperta, 3(2): 1-13. 